\title{
MOZ is essential for maintenance of hematopoietic stem cells
}

\author{
Takuo Katsumoto, ${ }^{1}$ Yukiko Aikawa, ${ }^{1}$ Atsushi Iwama, ${ }^{4}$ Shinobu Ueda, ${ }^{2}$ Hitoshi Ichikawa, ${ }^{3}$ \\ Takahiro Ochiya, ${ }^{2}$ and Issay Kitabayashi ${ }^{1,5}$ \\ ${ }^{1}$ Molecular Oncology Division, ${ }^{2}$ Section for Studies on Metastasis, and ${ }^{3}$ Cancer Transcriptome Project, National Cancer \\ Center Research Institute, 5-1-1 Tsukiji, Chuo-ku, Tokyo, 104-0045, Japan; ${ }^{4}$ Department of Cellular and Molecular \\ Medicine, Graduate School of Medicine, Chiba University, 1-8-1 Inohana, Chuo-ku, Chiba 260-8670, Japan
}

\begin{abstract}
Monocytic leukemia zinc-finger protein (MOZ), a MYST family histone acetyltransferase, is involved in the chromosome translocations associated with acute myeloid leukemia. MOZ acts as a transcriptional coactivator for AML1, which is essential for establishment of definitive hematopoiesis. To investigate the roles of $\mathrm{MOZ}$ in normal hematopoiesis, we generated $\mathrm{MOZ}$-null mice. $\mathrm{MOZ}^{-/-}$mice died around embryonic day 15 (E15). In $\mathrm{MOZ}^{-/-}$E14.5 embryos, hematopoietic stem cells, lineage-committed progenitors, and B lineage cells were severely reduced. On the other hand, arrest of erythroid maturation and elevated myeloid lineage populations were observed. MOZ-deficient fetal liver cells could not reconstitute hematopoiesis of recipients after transplantation. Analysis using microarray and flow cytometry revealed that expression of thrombopoietin receptor (c-Mpl), HoxA9, and c-Kit was down-regulated. These results show that MOZ is required for maintenance of hematopoietic stem cells, and that it plays a role in differentiation of erythroid and myeloid cells. Some aspects of the $\mathrm{MOZ}^{-/-}$phenotype are similar to that observed in PU.1-deficient mice. MOZ was able to interact with PU.1 and activate PU.1-dependent transcription, thus suggesting a physical and functional link between PU.1 and MOZ.
\end{abstract}

[Keywords: Hematopoiesis; stem cells; leukemia; histone acetyltransferase; transcriptional coactivator; PU.1]

Supplemental material is available at http://www.genesdev.org.

Received November 17, 2005; revised version accepted March 10, 2006.

Monocytic leukemia zinc-finger protein (MOZ) is a transcriptional coactivator with histone acetyltransferase activity (Champagne et al. 2001; Kitabayashi et al. 2001a). MOZ was first isolated as a gene involved in chromosome translocaton $\mathrm{t}(8 ; 16)(\mathrm{p} 11 ; \mathrm{p} 13)$, which is associated with the FAB M4/M5 subtype of acute myeloid leukemia with monocytic arrest (Borrow et al. 1996). This translocation results in the fusion of MOZ to transcription coactivator CBP. MOZ is also fused to CBP-like coactivator p300 and nuclear receptor coactivator TIF2 in leukemiaassociated chromosome rearrangements $\mathrm{t}(8 ; 22)$ (Chaffanet et al. 2000; Kitabayashi et al. 2001b), and inv(8) (Carapeti et al. 1998; Liang et al. 1998), respectively. In addition, MOZ is involved in the $\mathrm{t}(2 ; 8)$ chromosome translocation found in myelodysplastic syndrome (Imamura et al. 2003). In all of the leukemia-associated fusions, MOZ lacks the C-terminal region but retains some of its functional domains, including the histone acetyltransferase domain, PHD-type zinc-finger motif, and histone H1-like domain. MOZ-TIF2 fusion is able to

${ }^{5}$ Corresponding author.

E-MAIL ikitabay@gan2.ncc.go.jp; FAX 81-3-3542-0688.

Article and publication are at http://www.genesdev.org/cgi/doi/10.1101/ gad.1393106. confer properties of leukemic stem cells to committed hematopoietic progenitors, thus inducing acute myeloid leukemia in irradiated recipient mice after transplantation (Deguchi et al. 2003; Huntly et al. 2004). MOZ-CBP inhibits differentiation of M1 myeloid precursor cells into macrophages (Kitabayashi et al. 2001a).

It has been reported that MOZ interacts with AML1, and acts as a transcriptional coactivator (Kitabayashi et al. 2001a). AML1 (Runx1) is the most frequent target of chromosome rearrangements associated with acute leukemia. AML1 is essential for generation of hematopoietic stem cells (Okuda et al. 1996; Wang et al. 1996a), and is important for differentiation of megakaryocytes and lymphocytes (Ichikawa et al. 2004; Growney et al. 2005). AML1 forms a stable complex with CBF $\beta$, which is also essential for definitive hematopoiesis (Sasaki et al. 1996; Wang et al. 1996b; Niki et al. 1997). Although MOZ and p300/CBP act as coactivators for AML1, the leukemiaassociated MOZ-CBP inhibits AML1-mediated transcription (Kitabayashi et al. 1998, 2001a; Bristow and Shore 2003). The ETS family transcription factor PU.1 (Spi-1) is essential for maintenance of hematopoietic stem cells and development of myeloid and lymphoid lineages (Scott et al. 1994; McKercher et al. 1996; Kim et al. 2004; Iwasaki et al. 2005). Recent studies of mice 
carrying hypomorphic PU.1 alleles have indicated that reduction in the expression of PU.1 is capable of predisposing mice to AML (Rosenbauer et al. 2004).

Zebrafish having a mutation in the MOZ gene exhibit defects in Hox expression and pharyngeal segmental identity (Miller et al. 2004). Mice carrying a mutation in a gene encoding the MOZ-like protein MORF/Querkopf exhibited defects in bone and brain development (Thomas et al. 2000). However, the role of zebrafish MOZ and mouse MORF in hematopoiesis has not been described.

In order to clarify the physiological role of MOZ, we generated mutant mice that completely lack expression of MOZ. Involvement in leukemia-associated chromosome rearrangements and interaction with AML1 suggest critical roles of MOZ in hematopoiesis. Thus, we focused on analysis of the hematopoietic system in MOZ-null mice.

\section{Results}

\section{MOZ deficiency is embryonic lethal}

In order to clarify the roles of MOZ in hematopoiesis, we generated MOZ-deficient mice by homologous recombination in embryonic stem (ES) cells using a gene-targeting vector, in which the MOZ exon 2 containing the first ATG was replaced with the neo gene cassette (Fig. 1A). Western blot analysis showed no detectable MOZ in homozygous embryos and decreased expression of MOZ in heterozygous embryos (Fig. 1B). Western blot analysis using antibodies to detect $\mathrm{N}$-terminal and $\mathrm{C}$-terminal MOZ, and RT-PCR using different sets of primers on the $5^{\prime}$, central, and $3^{\prime}$ regions indicated that no truncated MOZ protein or mRNA was present in $\mathrm{MOZ}^{-/-}$embryos (Supplementary Fig. S1B). $\mathrm{MOZ}^{+/-}$mice were born and were fertile, exhibiting no morphological abnormalities (Fig. 1C). On the other hand, $\mathrm{MOZ}^{-/-}$pups were not seen. To identity the stage of embryonic development at which the MOZ mutation is lethal, embryonic day 12.516.5 (E12.5-E16.5) embryos were analyzed for genotype. $\mathrm{MOZ}^{-/-}$embryos remained alive until E14.5; however, after E15.5, viable MOZ-deficient fetuses were not detected (Fig. 1C). $\mathrm{MOZ}^{-/-}$embryos at E14.5 were pale, and the fetal liver, which is the major hematopoietic organ at this stage, was smaller than that of wild-type or heterozygous littermates (Fig. 1D). Some $\mathrm{MOZ}^{-/-}$embryos exhibited hemorrhaging, subcutaneous edema, and bent tail. Gross histological analysis of wild-type and null mutant littermates revealed that $\mathrm{MOZ}^{-/-}$embryos have no other notable defects or abnormalities (Fig. 1E). Two independent targeted lines were produced, and exhibited essentially the same phenotype.

\section{Decreased colony-forming cells in MOZ-deficient fetal} liver

The morphological features of $\mathrm{MOZ}^{-/-}$embryos suggest defects in fetal liver hematopoiesis. The total number of fetal liver cells was decreased by $40 \%$ in E14.5 $\mathrm{MOZ}^{-/-}$
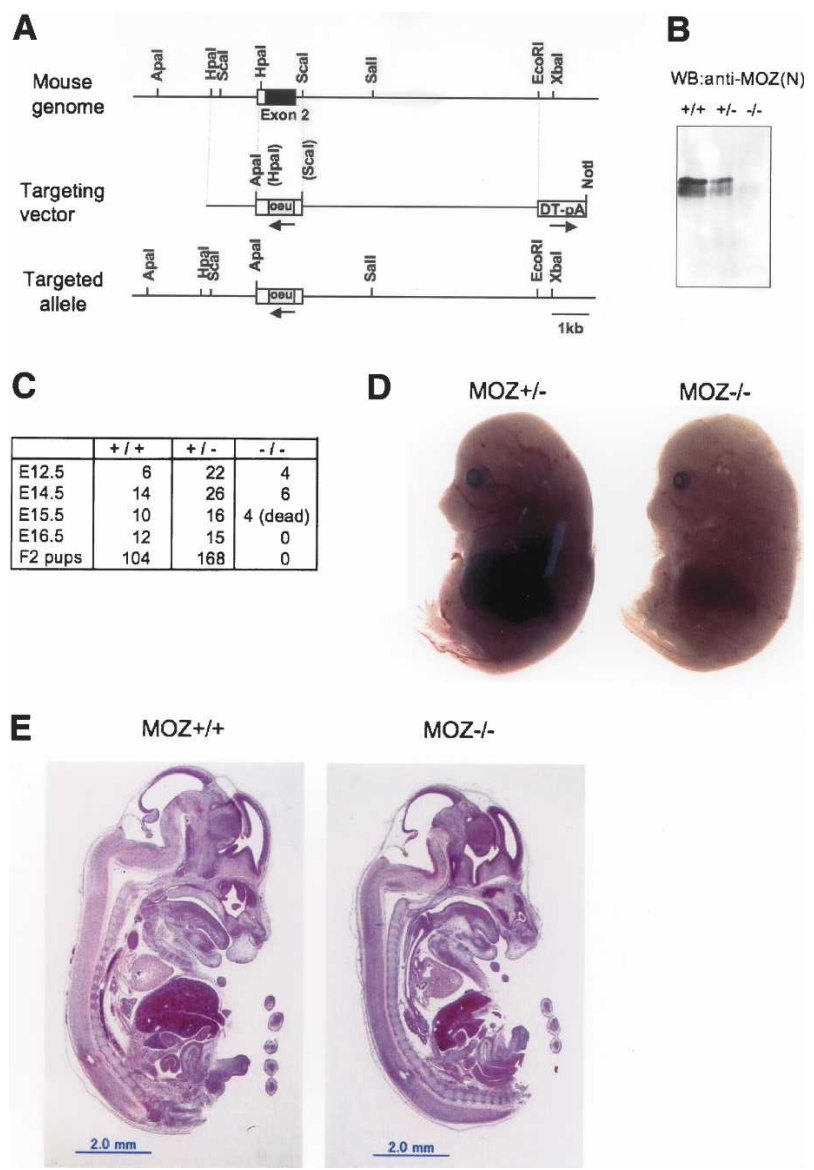

Figure 1. Targeted disruption of the mouse MOZ gene. $(A)$ Structure of the mouse $M O Z$ locus, the targeting construct, and the targeted locus. The targeting vector contains the HpaIEcoRI MOZ genomic fragment, in which exon 2 containing the first ATG is replaced with a $1.1-\mathrm{kb}$ pMC1-neor-poly $(A)$ cassette, and a 0.8-kb DT-A fragment at the 3 ' terminus. The open and filled boxes represent the noncoding and coding regions of MOZ exon 2, respectively. (B) Expression of MOZ protein in $\mathrm{MOZ}^{+/+}, \mathrm{MOZ}^{+/-}$and $\mathrm{MOZ}^{-/-}$embryos. Lysates were prepared from E12.5 embryos derived from $\mathrm{MOZ}^{+/-}$mice intercrosses, and were analyzed by Western blotting using anti-MOZ antibody. (C) Genotyping of offspring from $\mathrm{MOZ}^{+/-}$intercrosses was performed by PCR analysis using genomic DNAs from tails of adult mice and heads of embryos at the stages indicated. $(D)$ Phenotypic comparison of $\mathrm{MOZ}^{+/-}$and $\mathrm{MOZ}^{-/-}$embryos at E14.5. The $\mathrm{MOZ}^{-/-}$fetus appears pale and the liver is small. $(E)$ Sagital sections of E14.5 embryos of wild-type and null-mutant mice stained with hematoxylin and eosin.

embryos (Fig. 2A). To examine the presence of hematopoietic progenitors, colony-forming cells (CFCs) were analyzed. Fetal liver cells were cultured in methylcellulose medium, and myeloid, erythroid, and mixed-lineage colonies were scored on the basis of standard morphological criteria after $12 \mathrm{~d}$ of culture. The total number of CFCs in $\mathrm{MOZ}^{-/-}$fetal liver cells was decreased by fivefold to 10 -fold. However, the ratio of lineage-committed CFCs was not affected (Fig. 2B). These results suggest that the hematopoietic progenitor population was reduced in MOZ-deficient embryos. No significant differ- 
A

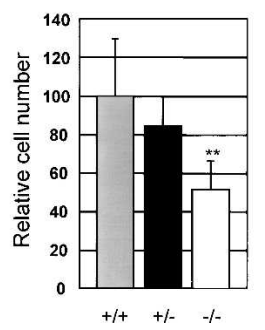

B

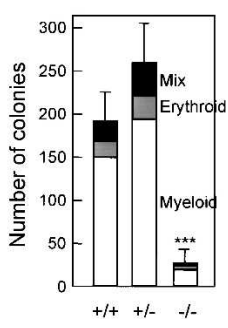

Figure 2. Reduction in cell number and colony-forming cells in $\mathrm{MOZ}^{-/-}$embryos. (A) Number of cells in fetal liver. Fetal livers from E14.5 $\mathrm{MOZ}^{+++}(n=6), \mathrm{MOZ}^{+/-}(n=23)$, and $\mathrm{MOZ}^{-/-}$ $(n=10)$ embryos were dispersed into single-cell suspensions and the number of cells was counted. $P$-values were calculated by two-tailed unequal-variance $t$-test, as compared with $\mathrm{MOZ}^{+/+}$ embyros. $\left(^{\star}\right) P<0.05$; $\left(^{\star \star}\right) P<0.01$. (B) Colony-forming cells in fetal liver. Approximately $1.5 \times 10^{4}$ fetal liver cells were cultured in $1 \%$ methylcellulose, and the number of mixed lineage, erythroid, and myeloid colonies was counted.

ence in total number of cells in the yolk sac was observed (Supplementary Fig. S1C), thus suggesting no defects in primitive hematopoiesis in $\mathrm{MOZ}^{-/-}$embryos.

Reduction of hematopoietic stem cells and progenitors in MOZ-deficient fetal liver

In order to analyze hematopoietic progenitors and stem cells directly, we performed flow cytometry. Analysis of c-Kit, a common marker for hematopoietic progenitors, revealed that the population of cells expressing high levels of $\mathrm{c}-\mathrm{Kit}\left(\mathrm{Lin}^{-} \mathrm{c}-\mathrm{Kit}^{\mathrm{hi}}\right)$ was severely decreased in $\mathrm{MOZ}^{-/-}$fetal liver, while the population of cells expressing low levels of c-Kit was not strongly affected (Fig. 3A). The population of $\mathrm{Lin}^{-} \mathrm{Sca}-1^{+} \mathrm{c}-\mathrm{Kit}^{+}$cells, which includes hematopoietic stem cells (HSCs), was severely reduced in $\mathrm{MOZ}^{-/-}$embryos when compared with wildtype controls (Fig. 3B). Reductions were also observed in lineage-committed progenitors, such as common lymphoid progenitors (CLPs, $\mathrm{Lin}^{-}$IL-7R $\alpha^{+}$Sca- $1^{1 \mathrm{lo}} \mathrm{c}-\mathrm{Kit}^{\mathrm{lo}}$ ) (Fig. 3B), common myeloid progenitors (CMPs, $\mathrm{Lin}^{-} \mathrm{Sca}-$

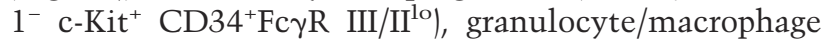
progenitors (GMPs, $\mathrm{Lin}^{-} \mathrm{Sca}-1^{-} \mathrm{c}-\mathrm{Kit}^{+} \mathrm{CD} 34^{+} \mathrm{Fc} \gamma \mathrm{R} \mathrm{III/}$ $\mathrm{II}^{+}$), and megakaryocyte/erythroid progenitors (MEPs, $\mathrm{Lin}^{-} \mathrm{Sca}-1^{-}{ }^{-}$- $\mathrm{Kit}^{+} \mathrm{CD} 34^{-}$Fc $\gamma \mathrm{R}$ III/III ${ }^{\mathrm{lo}}$ ) (Fig. 4A). The number of HSCs and progenitors was also reduced in E12.5 $\mathrm{MOZ}^{-/-}$fetal liver as compared with those in wild-type littermates, but the reductions were milder than those observed in E14.5 embryos (Supplementary Fig. S2). These data suggest that generation or maintenance of HSCs and progenitors was disrupted in $\mathrm{MOZ}^{-/}$embryos, and the number of HSCs and progenitors was slightly reduced in $\mathrm{MOZ}^{+/-}$embryos.

\section{Reduction of B lymphocytes, but not granulocytes and monocytes, in MOZ-deficient fetal liver}

In order to assess differentiated hematopoietic cells in fetal liver, we investigated cells expressing a B lineage marker, CD19, and myeloid lineage markers, Gr-1 and Mac- 1 by flow cytometry. $\mathrm{CD} 9^{+}$cells were reduced in $\mathrm{MOZ}^{-/-}$embryos when compared with wild-type embryos (Fig. 3C). In contrast, cell numbers of $\mathrm{Mac}^{-1^{+}}$ $\mathrm{Gr}-1^{\text {hi }}$ granulocytes and Mac- $1^{+} \mathrm{Gr}-1^{\text {lo }}$ monocytes were

A

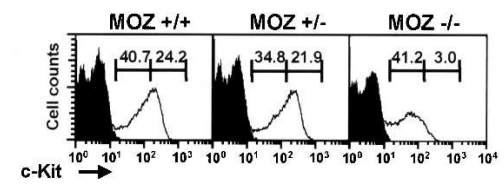

B
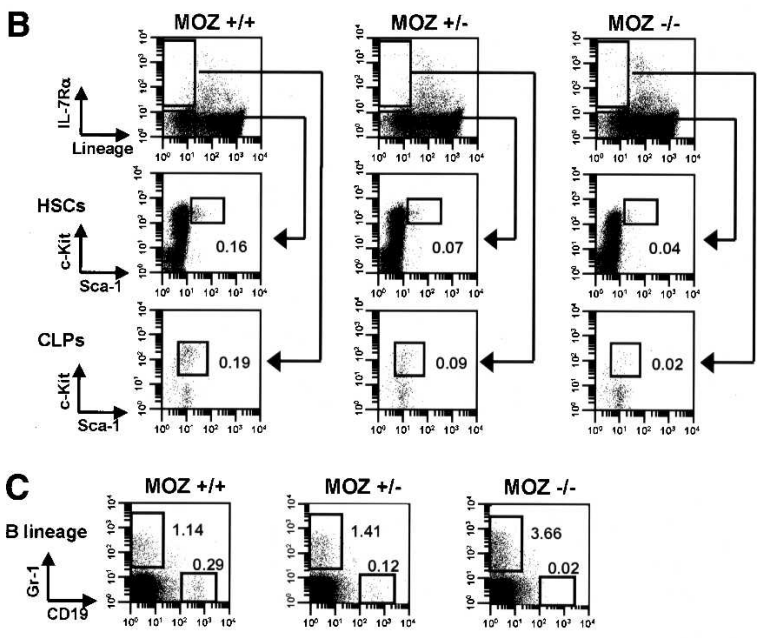

D

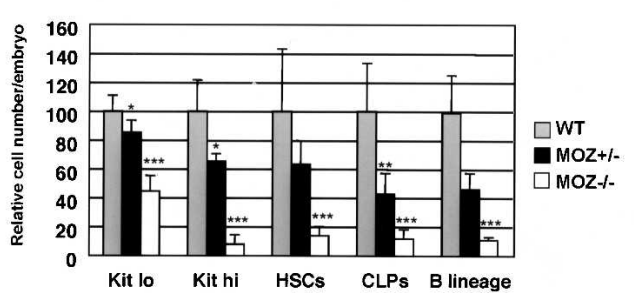

Figure 3. Decrease in hematopoietic stem cells and progenitors in $\mathrm{MOZ}^{-1-}$ fetal liver. $(A)$ Population of $\mathrm{c}-\mathrm{Kit}^{\mathrm{lo}}$ and $\mathrm{c}-\mathrm{Kit}^{\mathrm{hi}}$ cells. Cells were prepared from E14.5 fetal liver cells, stained with Lineage-Biotin-streptavidin-PerCP-Cy5.5 and c-Kit-APC. Populations of $\mathrm{c}-\mathrm{Kit}^{\mathrm{lo}}$ and $\mathrm{c}-\mathrm{Kit}^{\mathrm{hi}}$ cells in $\mathrm{Lin}^{-}$fractions were analyzed by flow cytometry. The filled area exhibits background staining. (B) Population of HSCs and CLPs. Cells from E14.5 fetal liver cells were stained with Sca-1-FITC, IL-7R $\alpha$-PE, Lineage (B220, CD3e, Gr-1, Ter119)-Biotin-streptavidin-PerCPCy5.5 and c-Kit-APC. Lin $^{-}$IL-7 $\alpha^{-}$Sca- $1^{+}$c-Kit ${ }^{+}$cells (HSCs) and $\mathrm{Lin}^{-} \mathrm{IL}-7 \mathrm{R}^{+}{ }^{+}$Sca- $1^{+}$c-Kit ${ }^{+}$cells (CLPs) were analyzed by flow cytometry. $(C)$ Population of B lymphocytes. Cells from E14.5 fetal liver cells were stained with CD19-PE and Gr-1APC. CD19 ${ }^{+} \mathrm{B}$ lineage cells and $\mathrm{Gr}-1^{+}$myeloid lineage cells were analyzed by flow cytometry. $(D)$ Numbers of c-Kit ${ }^{10}$ cells, c-Kit ${ }^{\text {hi }}$ cells, HSCs, CLPs, CD19+ B lineage cells, and Gr- $1^{+}$myeloid lineage cells. Results represent average values for the relative number of cells per embryo. E14.5 $\mathrm{MOZ}^{+/+}(n=6), \mathrm{MOZ}^{+/-}$ $(n=22)$ and $\mathrm{MOZ}^{-/-}(n=9)$ fetal livers were used for analysis of HSCs and CLPs. E14.5 $\mathrm{MOZ}^{+/+}(n=8), \mathrm{MOZ}^{+/-}(n=10)$, and $\mathrm{MOZ}^{-/-}(n=4)$ fetal livers were used for B lineage and myeloid cells. $P$-values were calculated by two-tailed unequal-variance $t$-test as compared with $\mathrm{MOZ}^{+/+}$embryos. $\left(^{\star}\right) P<0.05$; $\left.\left.\right|^{\star \star}\right)$ $P<0.01 ;\left(^{\star \star \star}\right) P<0.005$. 
A
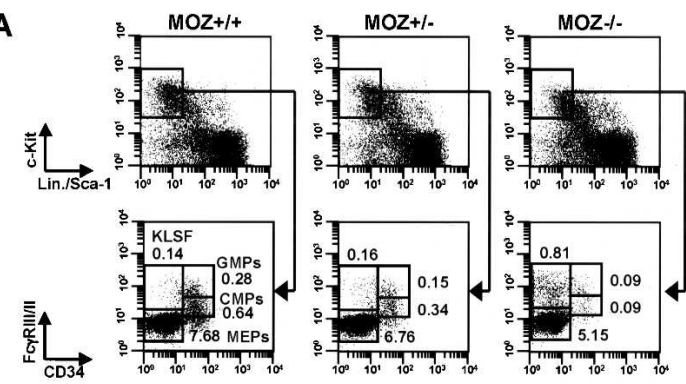

B

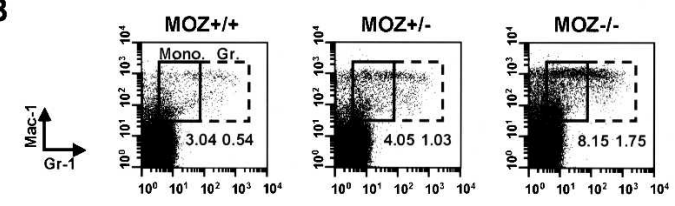

C

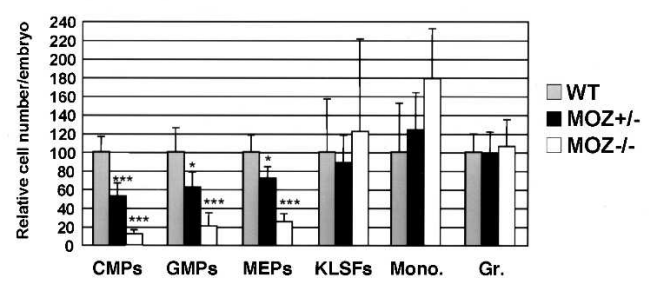

D

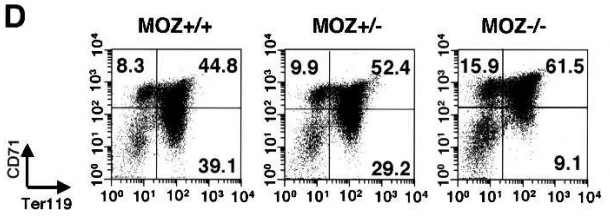

Figure 4. Changes in populations of myeloid and erythroid cells in $\mathrm{MOZ}^{-/-}$fetal liver. $(A)$ Population of myeloid progenitors. Cells obtained from E14.5 fetal liver cells were stained with Fc $\gamma$ R III/II-FITC, CD34-PE, Lin./Sca-1-Biotin-streptavidinPerCP-Cy5.5, and c-Kit-APC. Populations of common myeloid progenitors $\left(\mathrm{CMPs}, \mathrm{Lin}^{-} \mathrm{Sca}-1^{-} \mathrm{c}-\mathrm{Kit}^{+} \mathrm{CD} 34^{+} \mathrm{Fc} \gamma \mathrm{R} \quad \mathrm{III} / \mathrm{II}^{\mathrm{Io}}\right)$, granulocyte/macrophage progenitors (GMPs, $\mathrm{Lin}^{-} \mathrm{Sca}^{-1^{-} \mathrm{c}-\mathrm{Kit}^{+}}$ $\mathrm{CD}^{2} 4^{+}$Fc $\left.\gamma \mathrm{R} \quad \mathrm{III} / \mathrm{II}^{+}\right)$, megakaryocyte/erythroid progenitors (MEPs, $\mathrm{Lin}^{-} \mathrm{Sca}-1^{-} \mathrm{c}-\mathrm{Kit}^{+} \mathrm{CD} 34^{-} \mathrm{Fc} \gamma \mathrm{R} \mathrm{III} / \mathrm{II}^{\mathrm{lo}}{ }^{\circ}$, and KLSF fraction ( $\mathrm{Lin}^{-} \mathrm{Sca}-1^{-} \mathrm{c}-\mathrm{Kit}^{+} \mathrm{CD} 34^{-} \mathrm{Fc} \gamma \mathrm{R} \mathrm{III} / \mathrm{II}^{+}$) were analyzed by flow cytometry. (B) Myeloid lineage cells in $\mathrm{MOZ}^{-/-}$embryos. E14.5 fetal livers from $\mathrm{MOZ}^{+/+}, \mathrm{MOZ}^{+/-}$, and $\mathrm{MOZ}^{-/-}$embryos. Populations of granulocytic cells $\left(\mathrm{Gr}-1^{\text {hi }} / \mathrm{Mac}^{-1}{ }^{+}\right)$and monocytic cells $\left(\mathrm{Gr}-1^{\mathrm{lo}} / \mathrm{Mac}-1^{+}\right)$were analyzed by flow cytometry. $(C)$ Population of CMPs, GMPs, MEPs, KLSF fraction, granulocytic cells (Gr.), and monocytic cells (Mono.) in E14.5 fetal livers. Results represent the average values of the relative cell numbers of each cell fraction in $\mathrm{MOZ}^{+/+}(n=6), \mathrm{MOZ}^{+/-}(n=22)$, and $\mathrm{MOZ}^{-/-}(n=9)$ fetal livers. $(D)$ Erythroid differentiation is impaired in $\mathrm{MOZ}^{-/-}$embryos. Cells from E14.5 $\mathrm{MOZ}^{+/+}, \mathrm{MOZ}^{+/}$, and $\mathrm{MOZ}^{-/-}$embryos were stained with Ter119-biotin and CD71-PE followed by streptavidin-FITC and analyzed by flow cytometry.

not reduced in $\mathrm{MOZ}^{-/-}$embryos (Fig. 4C), but rather exhibited increased cell populations (Fig. 4B) in $\mathrm{MOZ}^{-/-}$ fetal liver.

During analysis of myeloid progenitors, we found that the population of the uncharacterized cell fraction KLSF
( Lin $^{-}$Sca- $1^{-}$c-Kit ${ }^{+}$CD34-Fc $\gamma \mathrm{R} \mathrm{III/II^{+ }}$ ) was also elevated (Fig. 4A). To characterize the KLSF fraction, we sorted KLSFs as well as GMPs from both wild-type and $\mathrm{MOZ}^{-/-}$ embryos by flow cytometry. Morphological assessment by May-Giemsa staining demonstrated that the KLSF fractions from both wild-type and $\mathrm{MOZ}^{-/-}$embryos contained more mature myeloid lineage cells than observed in the GMP fraction (Supplementary Fig. S4). These cells were also cultured in liquid and methylcellulose medium. After culture in liquid medium with cytokines for $4 \mathrm{~d}$, the majority of KLSFs and GMPs differentiated into either granulocytes or macrophages, although the differentiation of KLSFs was somewhat perturbed compared with that of GMPs. No significant differences in differentiation between wild-type and $\mathrm{MOZ}^{-/-}$cells were observed in the KLSF and GMP fractions before and after cultured in liquid medium. However, $\mathrm{MOZ}^{-/-}$GMPs and KLSFs exhibited poor proliferation and colony formation activity when compared with those from wild-type fetal liver (Supplementary Fig. S5). These results suggest that KLSFs contain not-yet characterized myeloid lineage cells that are relatively resistant to differentiation.

\section{Defects in erythropoiesis in MOZ-deficient fetal liver}

In order to investigate erythroid lineage differentiation, E14.5 fetal liver cells were simultaneously stained for transferrin receptor (CD71) and erythroid antigen Ter119, and were analyzed by flow cytometry (Socolovsky et al. 2001). While differentiated red cells $\left(\right.$ Ter $\left.119^{+} \mathrm{CD}^{-} 1^{-}\right)$were severely reduced, late-stage erythroblasts $\left(\right.$ Ter $\left.119^{+} \mathrm{CD} 71^{+}\right)$were elevated in $\mathrm{MOZ}^{-/-}$fetal liver when compared with wild-type or $\mathrm{MOZ}^{+/-}$controls (Fig. 4C). Morphological analysis of fetal liver cells indicated that erythroblasts were markedly accumulated in $\mathrm{MOZ}^{-/-}$embryos when compared with wild-type embryos (Supplementary Fig. S3). These data suggest that $\mathrm{MOZ}$ is indispensable for maturation of erythroid cells.

\section{MOZ is required for reconstituting the hematopoietic} system

We performed competitive reconstitution assay in order to determine whether MOZ-deficient embryos possess functional HSCs. Fetal liver cells $\left(2 \times 10^{5}\right.$ cells $)$ from E13.5-E14.5 $\mathrm{MOZ}^{+/+}, \mathrm{MOZ}^{+/-}$, and $\mathrm{MOZ}^{-/-}\left(\mathrm{Ly} 5.2^{+}\right) \mathrm{em}-$ bryos were injected into lethally irradiated normal recipient mice $\left(\operatorname{Ly} 5.1^{+} / 5.2^{+}\right)$together with an equal number of competitor fetal liver cells from wild-type E13.5E14.5 (Ly5.1 $1^{+}$embryos. Engraftment of recipient mice was monitored for $2,4,8$, or $12 \mathrm{wk}$ after transplantation by flow cytometry analysis of Ly 5 allotype expression in peripheral blood cells. As shown in Figure $5 \mathrm{~A}, \mathrm{MOZ}^{+/+}$ and $\mathrm{MOZ}^{+/-} \mathrm{Ly} 5.2^{+}$cells were detected in the recipient mice. However, $\mathrm{MOZ}^{-/-}$cells were not detected at any of the time points examined (Fig. 5B). The population of $\mathrm{MOZ}^{+/-}$cells was lower than that of wild-type cells. We also analyzed cells in the thymus, spleen, and bone marrow at $12 \mathrm{wk}$ after transplantation and found that Ly5.2 $2^{+}$ cells derived from $\mathrm{MOZ}^{-/-}$embryos were not present in any organs tested (Fig. 5C). 
A
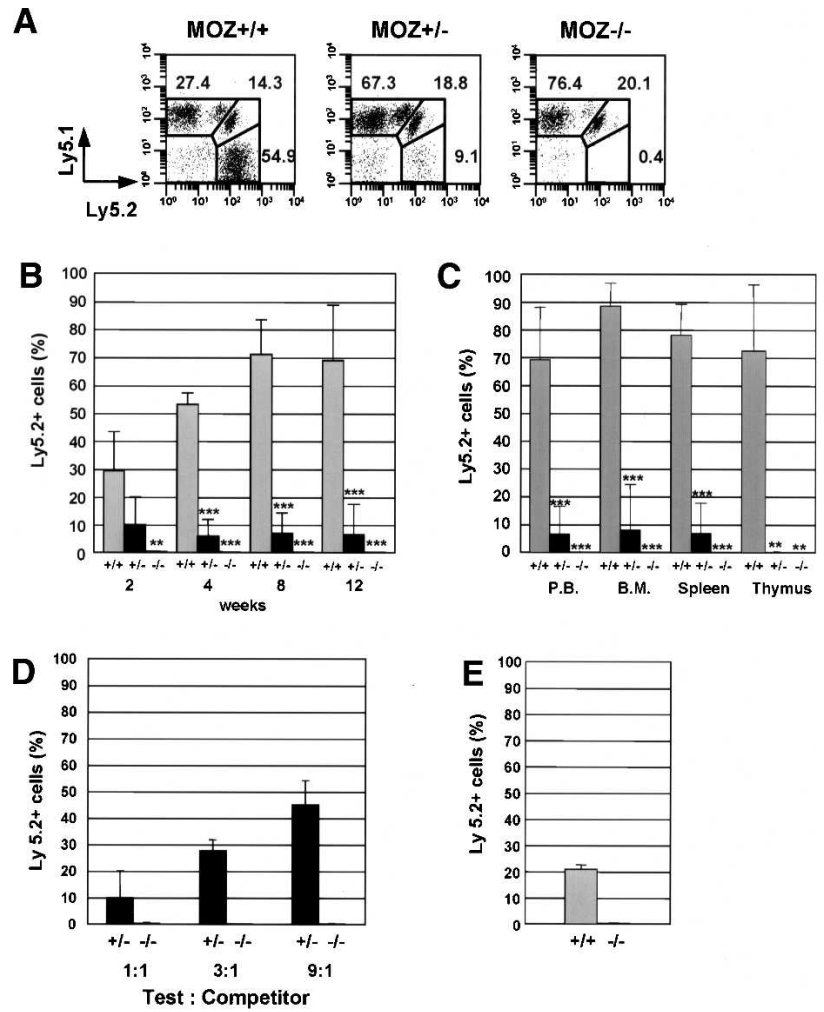

Figure 5. Analysis of reconstitution activity of $\mathrm{MOZ}^{-/-}$fetal liver cells. $(A-C)$ Fetal liver cells $\left(2 \times 10^{5}\right.$ cells $)$ from E14.5 $\mathrm{MOZ}^{+/+}, \mathrm{MOZ}^{+/-}$, and $\mathrm{MOZ}^{-/-}\left(\mathrm{Ly} 5.2^{+}\right)$embryos were injected into lethally irradiated normal recipient mice $\left(\operatorname{Ly} 5.1^{+} / 5.2^{+}\right)$together with an equal number of competitor fetal liver cells from wild-type E14.5 (Ly5.1 ${ }^{+}$) embryos. Peripheral blood cells of recipients were analyzed for Ly5.1/Ly5.2 expression by flow cytometry at 2, 4, 8, or $12 \mathrm{wk}$ after transplantation. Representative results at 4 wk are shown in $A$. A summary of the population of Ly5.2+ cells at $2,4,8$, or $12 \mathrm{wk}$ is shown in $B$. $(C)$ In addition to peripheral blood, bone marrow cells, thymocytes, and splenocytes were also analyzed at $12 \mathrm{wk}$ after transplantation. Results represent the average values for the population of Ly $5.2^{+}$cells. $(D)$ Competitive reconstitution assay using increasing numbers of donor cells. Fetal E14.5 $\mathrm{MOZ}^{+/-}$and $\mathrm{MOZ}^{-/-}$liver cells $\left(\right.$ Ly5.2 $\left.2^{+}\right)\left(2 \times 10^{5}\right.$ [1:1], $6 \times 10^{5}$ [3:1], $1.8 \times 10^{6}$ [9:1]) were injected into lethally irradiated normal recipient mice $\left(\operatorname{Ly} 5.1^{+} / 5.2^{+}\right)$together with competitor fetal liver cells $\left(2 \times 10^{5}\right)$ from wild-type E14.5 (Ly5. $\left.1^{+}\right)$embryos. Peripheral blood cells of recipients were analyzed for Ly5.1/Ly5.2 expression by flow cytometry at 2 wk after transplantation. Results represent the average values for the population of Ly5.2+ cells. (E) Reconstitution activity of E13.5 $\mathrm{MOZ}^{+/+}$and $\mathrm{MOZ}^{-/-}$fetal liver cells. The average values for the population of Ly5.2+ cells at $2 \mathrm{wk}$ in recipient peripheral blood are shown.

In order to determine whether loss of reconstitution activity was due to reductions in the number of HSCs or loss of HSC self-renewal activity, competitive reconstitution assay was performed using increasing numbers of donor cells (threefold and ninefold) (Fig. 5D). $\mathrm{MOZ}^{-/-}$ cells were not detected in the recipient mice under any conditions, while increased population of $\mathrm{MOZ}^{+/-}$cells were detected when increased numbers of cells were in- jected. $\mathrm{MOZ}^{-/-}$fetal liver cells from an earlier embryonic time point (E13.5) also failed to exhibit reconstitution activity (Fig. 5E). These results suggest that loss of HSC activity was not due to reductions in HSCs or loss of HSC viability. Thus, MOZ is required for HSC activity to reconstitute hematopoiesis in recipients.

\section{Reduced expression of HoxA9 and c-Mpl in $\mathrm{MOZ}^{-/-}$ fetal liver cells}

In order to identify genes with altered expression levels in $\mathrm{MOZ}^{-/-}$fetal liver cells, total RNAs were extracted from E12.5 $\mathrm{MOZ}^{+/}, \mathrm{MOZ}^{+/-}$, and $\mathrm{MOZ}^{-/-}$fetal livers. Analysis by oligonucleotide microarray identified 48 and 163 genes exhibiting changes in expression of more than twofold (Fig. 6A) and 1.5-fold (Supplementary Fig. S6), respectively. Among the former 48 genes, down-regulation of the homeobox transcription factor HoxA9 and the thrombopoietin receptor c-Mpl are likely to be associated with defects in hematopoiesis. Semiquantitative RT-PCR also showed that expression levels of HoxA9 and c-Mpl were apparently reduced in $\mathrm{MOZ}^{-/-}$fetal liver cells (Fig. 6B). Among the latter 163 genes, reduced expression of c-Kit was also observed in $\mathrm{MOZ}^{-/-}$fetal liver cells (Supplementary Fig. S6).

Expression levels of these genes was then investigated in HSCs by sorting HSC-enriched $\mathrm{Lin}^{-} / \mathrm{Sca}-1^{+}$fetal liver cells from E14.5 wild-type and $\mathrm{MOZ}^{-/-}$embryos, and preparing total RNAs. Semiquantitative RT-PCR analysis showed that expression levels of HoxA9, c-Kit, and c-Mpl were apparently reduced in $\mathrm{MOZ}^{-/-} \mathrm{Lin}^{-} / \mathrm{Sca}-1^{+}$ cells (Fig. 6C).

\section{Interaction of MOZ with PU.1}

The defects in hematopoiesis in MOZ-null mice are similar to those observed in PU.1 $1^{-/-}$mice. In PU.1 $1^{-/-}$ fetal liver, HSCs and progenitors, in particular, the population of $\mathrm{c}-\mathrm{Kit}^{+} \mathrm{Lin}^{-}$cells is severely reduced (Kim et al. 2004; Iwasaki et al. 2005). These similarities suggest a functional link between MOZ and PU.1. To test whether MOZ interacts with PU.1, we performed coimmunoprecipitation analysis. HA-tagged MOZ was transfected with Flag-tagged PU.1, AML1, C/EBP $\alpha$, and C/EBP $\varepsilon$. Cell lysates were prepared, and were immunoprecipitated with anti-Flag antibodies. Western blot analysis of the immunoprecipitates indicated that MOZ was coprecipitated with PU.1 and AML1, but not with $\mathrm{C} / \mathrm{EBP} \alpha$ and C/EBPe (Fig. 7A). Reciprocal immunoprecipitation analysis indicated that PU.1 was coprecipitated with MOZ (Fig. 7B). To test the interaction between endogenous MOZ and PU.1, we performed coimmunoprecipitation analysis using lysates of E14.5 fetal liver cells. Endogenous MOZ was detected in immunoprecipitates of endogenous PU.1 (Fig. 7C). These results suggest that MOZ is able to physically interact with PU.1. To test the effects of MOZ on PU.1-regulated transcription activity, reporter analysis was performed. MOZ strongly stimulated PU.1-mediated transcriptional activation (Fig. 7D). These results suggest that MOZ functions as a transcriptional coactivator for PU.1. 
Katsumoto et al.

A

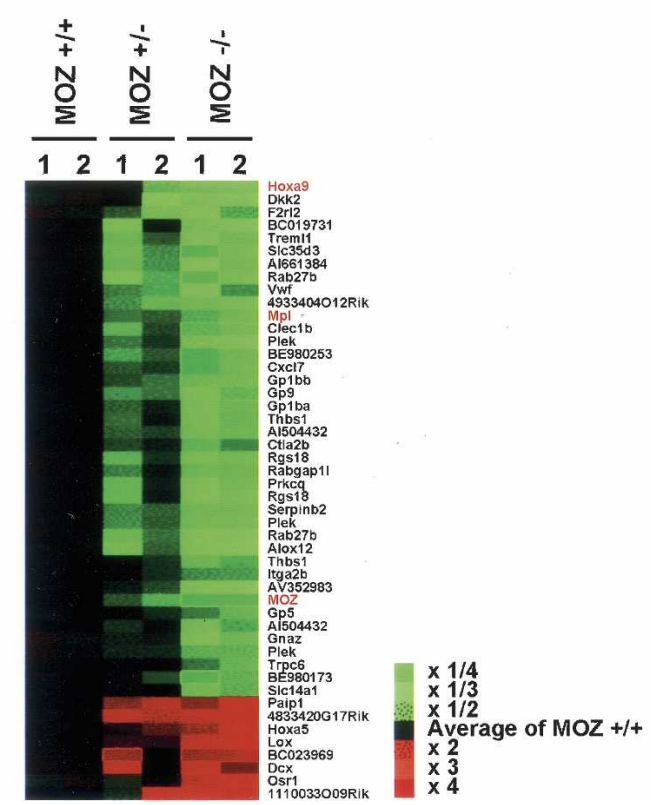

B

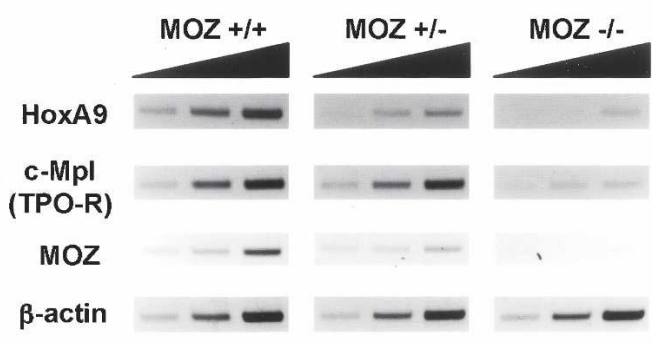

C

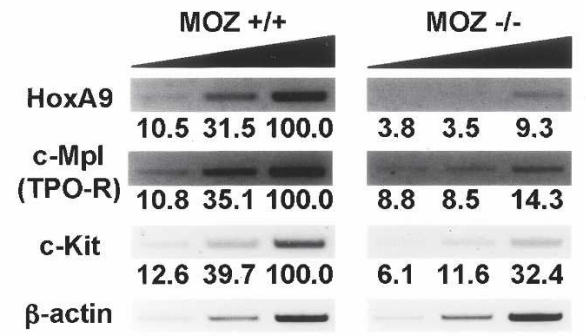

Figure 6. Expression levels of HoxA9 and c-Mpl were reduced in $\mathrm{MOZ}^{-/-}$fetal liver. (A) Gene expression profiling analysis. Total RNAs were purified from livers of two E12.5 $\mathrm{MOZ}^{+/+}, \mathrm{MOZ}^{+/-}$, and $\mathrm{MOZ}^{-/-}$embryos and were analyzed by oligonucleotide microarray. The 48 genes exhibiting changes in expression of more than twofold are shown. (B) RT-PCR analysis. Expression levels of HoxA9, $\mathrm{c}-\mathrm{Mpl}, \mathrm{MOZ}$, and $\beta$-actin were analyzed by semiquantitative RT-PCR analysis using threefold serial dilutions of cDNA as templates. (C) Expression of HoxA9, c-Mpl, and c-Kit in $\mathrm{Lin}^{-} / \mathrm{Scal}^{+}$cells. $\mathrm{Lin}^{-} / \mathrm{Scal}^{+}$cells were sorted from E14.5 $\mathrm{MOZ}^{+/+}$and $\mathrm{MOZ}^{-/-}$fetal livers using a flow cytometer. Expression levels of HoxA9, c-Mpl, c-Kit, and $\beta$-actin were analyzed by semiquantitative RT-PCR analysis using threefold serial dilution of cDNAs as templates. The relative intensities of the band are shown.

\section{Discussion}

In this study, we generated MOZ-deficient mice and demonstrated that MOZ is essential for definitive hematopoiesis. HSCs and progenitors were decreased, and maturation of erythroid cells was inhibited in MOZ-deficient fetal liver. In competitive repopulation assay, $\mathrm{MOZ}^{-/-}$fetal liver cells did not exhibit any activity to reconstitute hematopoietic system. These results indicate that MOZ is essential for maintenance of HSCs. Intermediate phenotypes in the number of HSCs and progenitors as well as in reconstitution activity were observed in $\mathrm{MOZ}^{+/-}$fetal liver cells, thus suggesting a gene dosage requirement for MOZ. Gene expression profiles showed that expression of HoxA9, c-Mpl, and c-Kit was diminished. Immunoprecipitation analysis and reporter analysis suggest that MOZ functions as a coactivator for PU.1 as well as AML1.

\section{Targets of MOZ}

Expression levels of HoxA9, c-Mpl, and c-Kit were significantly decreased in $\mathrm{MOZ}^{-/-}$fetal liver cells and HSCenriched $\mathrm{Lin}^{-} / \mathrm{Sca}-1^{+}$cells. HoxA9 has key roles in hematopoiesis (Lawrence et al. 1997; So et al. 2004) and leukemia pathogenesis (Kroon et al. 1998; Calvo et al. 2000). It has been reported that loss of HoxA9 reduces the proliferation and repopulating potential of hematopoietic stem cells, although HoxA9 is not essential for the maintenance of HSCs (Lawrence et al. 2005). The TPO receptor c-Mpl is important for megakaryocyte development (Carver-Moore et al. 1996) and for HSC activity in reconstituting hematopoietic organs in irradiated recipients (Kimura et al. 1998). c-Kit-mutated Vickid and $\mathrm{Kit}^{\mathrm{Wv} / \mathrm{Wv}}$ mice also exhibited reduced HSC repopulating activity (Waskow et al. 2002; Antonchuk et al. 2004). Moreover, reduced progenitors and repopulating activities, as well as defects in erythropoiesis, were exacerbated in c-Mpl- and c-Kit double-deficient mice (Antonchuk et al. 2004). In addition, the c-Mpl ligand, TPO, induces HOXA9 nuclear localization (Kirito et al. 2004). Therefore, it is possible that defects in HSC repopulating activity and erythropoiesis in $\mathrm{MOZ}^{-/-}$mice are due to the synergistic effects of decreased expression of these factors.

In E14.5 $\mathrm{MOZ}^{-/-}$fetal liver, populations of HSCs and all lineages of hematopoietic progenitors were reduced, particularly progenitors expressing high levels of c-Kit. These phenotypes were, at least in part, similar to those observed in PU. $1^{-/-}$mice. In PU. $1^{-/-}$fetal liver, HSCs and progenitors, except for MEPs, were severely reduced (Kim et al. 2004; Iwasaki et al. 2005). The population of Lin $^{-} \mathrm{c}-\mathrm{Kit}^{+}$cells was particularly low, thus suggesting that expression of c-Kit is positively regulated by PU.1. We showed here that MOZ is able to interact with PU.1 and activates PU.1-dependent transcription, which suggests that MOZ is a coactivator of PU.1 and that it regu- 
A

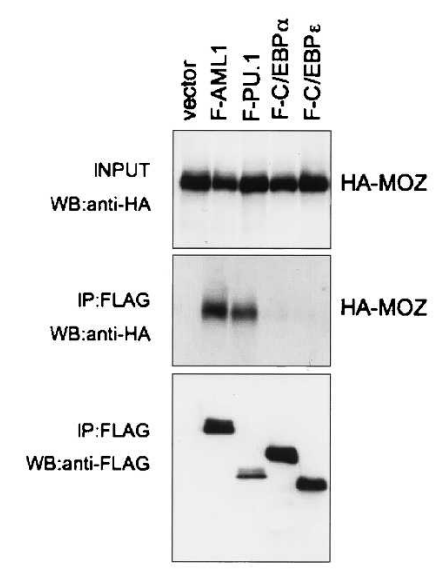

B

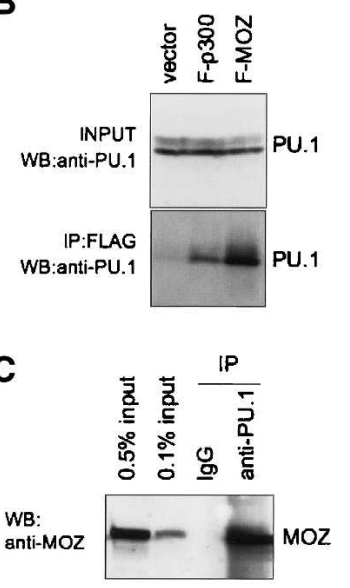

D

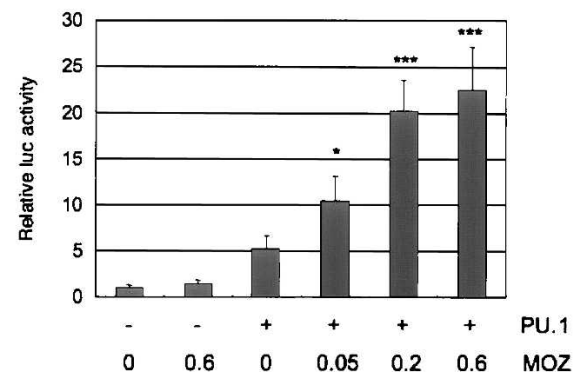

Figure 7. Interaction between $\mathrm{MOZ}$ and PU.1. $(A) \mathrm{MOZ}$ interacts with PU.1 and AML1 but not with C/EBP $\alpha$ and C/EBP $\varepsilon$. $293 \mathrm{~T}$ cells were cotransfected with HA-tagged MOZ, together with control vector, Flag-tagged AML1, PU.1, C/EBP $\alpha$ or C/EBPE. (Top) Expression of MOZ in the lysates of transfectants was detected by immunoblotting using anti-HA (3F10) antibody. Proteins were immunoprecipitated with anti-Flag (M2) antibody. Immunoprecipitates were analyzed by immunoblotting using anti-HA (middle) and anti-Flag (bottom) antibodies. $(B$, top $)$ Reciprocal coimmunoprecipitation of PU.1 and MOZ. 293 T cells were cotransfected with PU.1 together with control vector, Flag-tagged p300, or MOZ. Expression of PU.1 in the lysates of transfectants was detected by immunoblotting using anti-PU.1 antibody. Flag-tagged p300 and MOZ were immunoprecipitated with anti-Flag (M2) antibody. (Bottom) Immunoprecipitates were analyzed by immunoblotting using anti-PU.1 antibody. $(C)$ Interaction of endogenous PU.1 and MOZ. Cell lysates were prepared from E14.5 fetal liver cells $\left(5 \times 10^{7}\right)$ and PU.1 was immunoprecipitated with anti-PU.1 antibody. Cell lysates and immunoprecipitates were then analyzed by immunoblotting with anti-MOZ antibody (N). (D) MOZ activates PU.1-mediated transcription. SaOS2 cells were transfected with $100 \mathrm{ng}$ of M-CSFR-luc, $50 \mathrm{ng}$ of CMV-PU.1, indicated amounts (in micrograms) of LNCX-MOZ, and 2 ng of phRL-cmv. Cell lysates were prepared at $24 \mathrm{~h}$ after transfecton, and were analyzed for luciferase activity.

lates transcription of PU.1-target genes. PU.1 $1^{-/-}$mice show more severe reductions in HSCs and hematopoietic progenitors than $\mathrm{MOZ}^{-/-}$mice. MOZ is a transcription coactivator, and thus the difference may be because PU.1 transcription activity is not completely abolished in $\mathrm{MOZ}^{-/-}$mice. Therefore, MORF, which is highly homologous to $\mathrm{MOZ}$, may compensate for some $\mathrm{MOZ}$

functions. In contrast to $\mathrm{MOZ}^{-/-}$embryos, PU.1-null embryos have no myeloid cells (Kim et al. 2004; Iwasaki et al. 2005). However, increases in myeloid cells were observed in mice carrying hypomorphic PU.1 alleles, in which PU.1 expression was decreased to $20 \%$ of wildtype levels (Rosenbauer et al. 2004) as observed in $\mathrm{MOZ}^{-/-}$embryos. Thus, the $\mathrm{MOZ}^{-/-}$mouse phenotype, except for defects in erythropoiesis and reductions in MEPs, can be explained by reduced PU.1 activity.

We previously showed that MOZ forms a complex with AML1 and acts as a potent coactivator of AML1 (Kitabayashi et al. 2001a). HoxA9 expression is reduced in AML patients with chromosome translocations $\mathrm{t}(8: 21)$ and inv(16) (Debernardi et al. 2003). In such leukemia cells, AML1 is inhibited by AML1-ETO and CBF $\beta$ MYH11, respectively. Expression of c-Mpl is also reduced in patients having familial platelet disorder with predisposition to acute myeloid leukemia (FPD/AML), which has a mutation in AML1 (Heller et al. 2005). These studies indicate that expression of HoxA9 and c$\mathrm{Mpl}$ can be regulated by AML1. Thus, it is likely that reduced expression of HoxA9 and $\mathrm{c}-\mathrm{Mpl}$ in $\mathrm{MOZ}^{-/-}$fetal liver arises from the inactivity of AML1 in the absence of its coactivator, $\mathrm{MOZ}$.

\section{Roles of MOZ and MOZ fusion in myelogenesis and leukemia pathogenesis}

We observed increases in the populations of $\mathrm{Mac}^{-1}{ }^{+} \mathrm{Gr}-$ $1^{+}$myeloid cells and in the uncharacterized myeloid cell fraction KLSF $\left(\mathrm{Lin}^{-} \mathrm{Sca}-1^{-} \mathrm{c}-\mathrm{Kit}^{+} \mathrm{CD} 34^{-} \mathrm{Fc} \gamma \mathrm{R} \mathrm{III/} / \mathrm{II}^{+}\right)$in MOZ-deficient fetal liver (Fig. 4A,B), although immature myeloid progenitors (CMP, GMP) were reduced. This may be because myeloid differentiation is inhibited around the KLSF stage in $\mathrm{MOZ}^{-/-}$mice, as MOZ has important roles in the regulation of this stage. Alternatively, accumulation of myeloid cells including KLSFs may be due to uncontrolled and abnormal differentiation of the myeloid lineage. Consistent with the latter hypothesis, analysis of the flow-sorted KLSF fraction indicated that KLSFs contained myeloid lineage cells showing less differentiation activity than GMPs (Supplementary Fig. S4). Increases in myeloid cells were also observed in conditional AML1-KO mice (Growney et al. 2005) and in hypomorphic PU.1 mice (Rosenbauer et al. 2004). Interestingly, KLSF cells were substantially elevated in mice with acute myeloid leukemia after transplantation of MOZ-TIF2-introduced bone marrow cells (Deguchi et al. 2003; Huntly et al. 2004). In addition, monocytic blasts are often elevated in human leukemia patients who exhibit rearrangement of MOZ. Taken together with previous results (Deguchi et al. 2003; Huntly et al. 2004), the present study suggests that MOZ fusion modulates normal MOZ function in the pathogenesis of leukemia, and that the KLSF fraction plays a role in the development of acute myeloid leukemia. Recent studies have indicated that mice carrying hypomorphic PU.1 alleles in which PU.1 expression is decreased to $20 \%$ of wild-type levels develop acute myeloid leukemia (Rosenbauer et al. 2004). The interaction between MOZ and 
PU.1 suggests that MOZ fusion may affect function of PU.1 in the pathogenesis of leukemia.

\section{Materials and methods}

\section{Generation of MOZ-deficient mice}

MOZ genomic clones were isolated from a mouse genomic BAC library by PCR screening. We constructed a targeting vector containing an MOZ genomic fragment interrupted in exon 2, which contains the first methionine ATG, using a neomycin resistance gene (neo) cassette with a flanking diphtheria toxin A fragment gene (DT-A) cassette. The construct was electroporated into ES cells, and G418-resistant clones were selected by Southern blot analysis using $5^{\prime}$ and $3^{\prime}$ external probes. Nine clones containing the MOZ-disrupted allele were obtained. Two independent clones were injected into day 3.5 C57BL/6J JcL embryos, which were subsequently transferred to CD-1 recipient females. All animals were maintained under specific pathogen-free, temperature-controlled conditions throughout this study, in accordance with Institutional Guidelines. Written approval for all animal experiments was obtained from the local Animal Experiments Committee of the National Cancer Center Research Institute.

\section{Histological procedures}

Embryos were isolated at E14.5 and fixed in 4\% paraformaldehyde in phosphate-buffered saline (PBS) for $48 \mathrm{~h}$. Embryos were routinely processed for embedding in paraffin and $3-\mu \mathrm{m}$ sections were cut for hematoxylin and eosin staining.

\section{In vitro hematopoietic colony assays}

Fetal livers from E14.5 embryos were dispersed into single-cell suspensions and cultured in 1\% methylcellulose in Iscove's modified Dulbecco's medium (IMDM) containing $15 \%$ fetal bovine serum (FBS), $1 \%$ bovine serum albumin (BSA), $10 \mu \mathrm{g} / \mathrm{mL} \mathrm{rh}$ Insulin, $200 \mu \mathrm{g} / \mathrm{mL}$ human transferrin, $100 \mu \mathrm{M}$ 2-mercaptoethanol, $2 \mathrm{mM}$ L-glutamine, $50 \mathrm{ng} / \mathrm{mL} \mathrm{rm} \mathrm{SCF}, 10 \mathrm{ng} / \mathrm{mL}$ rmIL-3, 10 $\mathrm{ng} / \mathrm{mL}$ rh IL-6, and $3 \mathrm{U} / \mathrm{mL}$ Erythropoietin (METHOCULT GF M3434) (Stemcell Technology, Inc.). Cultures were maintained at $37^{\circ} \mathrm{C}$ under humidified conditions with $5 \% \mathrm{CO}_{2}$. Colonies containing $>50$ cells were counted on day 12, and myeloid CFUs, erythroid burst forming units (BFU-E), and CFU-Mix were defined based on morphology.

\section{Immunofluorescent staining and flow cytometric analysis}

Fetal liver cells were dissected from E12.5 and E14.5 embryos, and drawn through 21- and 25-gauge needles to generate a single-cell suspension. Erythrocytes were lysed in ammonium chloride potassium buffer. One-million cells were preincubated with 2.4G2 in order to prevent nonspecific binding of $\mathrm{mAb}$ via FcR interactions, and were then incubated on ice for $90 \mathrm{~min}$ with the appropriate staining reagents according to standard methods (Nakayama et al. 1990). Flow cytometry was performed on a FACScalibur (Becton Dickinson), and the results were analyzed using CELLQUEST software (Becton Dickinson). The reagents used in this study were as follows: FITC-conjugated streptavidin, PerCP-Cy5.5-conjugated streptavidin, antiFc $\gamma$ R III/II-FITC (2.4G2-FITC), anti-Mac-1-FITC (M1/70-FITC), anti-Sca-1-FITC (E13-161.7-FITC), anti-CD19-PE (1D3-PE), anti-CD45.2-FITC (104-FITC), anti-CD34-PE (RAM34-PE), antiCD45.1-PE (A20-PE), anti-CD71-PE (C2-PE), IL-7R $\alpha$-PE (SB/199$\mathrm{PE})$, anti-CD3 $\varepsilon$-Biotin (145-2C11-Biotin), anti-Mac-1-Biotin (M1/70-Biotin), anti-B220-Biotin (RA3-6B2-Biotin), anti-Gr-1-
Biotin (RB6-8C5-Biotin), anti-Sca-1-Biotin (E13-161.7-Biotin), anti-TER119-Biotin (TER119-Biotin), anti-c-Kit-APC (2B8APC), and anti-Gr-1-APC (RB6-8C5-APC). All of the above reagents were purchased from PharMingen. Anti-CD45.2-APC (104-APC) was purchased from eBioscience.

\section{Purification and liquid culture of fetal liver hematopoietic cells}

E14.5 fetal liver cells were stained with biotinylated anti-Gr-1, B220, CD4, CD8, and Ter-119 mAbs and PE-conjugated antiSca-1 to obtain Lin $^{-}$Sca- ${ }^{+}$cells, or biotinylated anti-Gr-1, B220, CD4, CD8, Ter-119, IL-7 receptor $\alpha$, and Sca- 1 mAbs, APCconjugated anti-c-Kit, PE-conjugated Fcy receptor II/III, and FITC-conjugated anti-CD34 mAbs to obtain GMP and KLSF cells. Biotinylated antibodies were detected with streptavidinAPC-Cy7 (eBioscience). Four-color analysis and cell sorting were performed on a JSAN cell sorter (Bay Bioscience). GMP and KLSF cells from wild-type and $\mathrm{MOZ}^{-/-}$fetal livers were directly sorted into 96-well plates at 2000 cells per well containing 200 $\mu \mathrm{L}$ of IMDM supplemented with $10 \% \mathrm{FBS}, 20 \mathrm{ng} / \mathrm{mL}$ mouse SCF, IL-3, IL-11, GM-CSF, $50 \mathrm{ng} / \mathrm{mL}$ human thrombopoietin, and $2 \mathrm{U} / \mathrm{mL}$ erythropoietin (Peprotech). Cell numbers were counted at day 5. Cells were then recovered, cytospun onto glass slides, and subjected to May-Grüenwald Giemsa staining for morphological examination. Sorted GMP and KLSF cells were also plated in methylcellulose medium (Stem Cell Technologies) supplemented with $20 \mathrm{ng} / \mathrm{mL}$ mouse SCF, IL-3, IL-11, GM-CSF, $50 \mathrm{ng} / \mathrm{mL}$ human thrombopoietin, and $2 \mathrm{U} / \mathrm{mL}$ erythropoietin. The number of colonies (>100 cells) and clusters $(20$ 100 cells) was counted on day 6.

\section{Competitive repopulation assay}

Competitive repopulation assay was performed using the Ly5 congenic mouse system. Fetal liver cells $\left(2 \times 10^{5}, 6 \times 10^{5}\right.$, or $18 \times 10^{5}$ cells) from test Ly5.2 mice were mixed with $2 \times 10^{5}$ cells of fetal liver competitor cells (C57BL/6-Ly5.1) and were transplanted into C57BL/6-Ly5.1/Ly5.2 recipient mice irradiated at a dose of $9.5 \mathrm{~Gy}$. Peripheral blood cells of recipient mice were stained with anti-Ly5.1 and Ly5.2 antibody, and were analyzed for populations of Ly5.1+ cells and Ly5.2 ${ }^{+}$cells at 2, 4, 8, and 12 wk after transplantation. At 12 wk after transplantation, peripheral blood cells, thymocytes, splenocytes, and bone marrow cells from recipient mice were also analyzed. C57BL/6Ly5.1 mice were kindly provided by Dr. Hiromitsu Nakauchi (Tokyo University, Tokyo, Japan).

\section{Microarray analysis and RT-PCR}

For gene expression analysis, total RNA was isolated using Isogen reagent (Nippon Gene) from livers of two each of E12.5 $\mathrm{MOZ}^{+/+}, \mathrm{MOZ}^{+/-}$, and $\mathrm{MOZ}^{-/-}$embryos, and were purified with an RNeasy MinElute cleanup kit (Qiagen). The integrity of total RNA was confirmed using LabChip RNA 6000 Nano chips and a 2100 Bioanalyzer (Agilent Technologies). For gene expression profiling, a GeneChip Mouse Genome 4302.0 oligonucleotide microarray (Affymetrix), which contained 45,037 probe sets, was used according to the manufacturer's instructions.

The expression value (Signal) of each gene was calculated and normalized using GeneChip Operating Software version 1.2 (Affymetrix). The change value (Signal Log Ratio) and change call (Increase, Marginal Increase, No Change, Marginal Decrease, or Decrease) for each gene was calculated by Comparison Analysis of the software. To identify genes that were significantly affected by MOZ knockout, we selected genes that showed a change call of Increase and a Signal Log Ratio of more than 1 (more than twofold increase) or genes that showed a change call 
of Decrease and a Signal Log Ratio of less than -1 (more than twofold decrease) in all four comparisons between $\mathrm{MOZ}^{-/-}$and $\mathrm{MOZ}^{+/+}$fetal livers.

Total RNA was isolated using Isogen LS reagent (Nippon Gene) from fetal liver Lin $^{-} / \mathrm{Sca}-1^{+}$cells of two E14.5 C57BL/6 and $\mathrm{MOZ}^{-/-}$embryos. Reverse transcription of total RNA isolated from E12.5 fetal liver and E14.5 $\mathrm{Lin}^{-} / \mathrm{Sca}-1^{+}$cells was performed using SuperScript III (Invitrogen Life Technologies). Threefold serial dilutions of template cDNA were obtained as described previously (Kimura et al. 2001). Primers and conditions used in the RT-PCR study were as follows: for HoxA9, 5' -ACAATGCCGAGAATGAGAGC-3' and 5'-CATTTTCATC CTGCGGTTCT- $3^{\prime}$, with 36 cycles at $95^{\circ} \mathrm{C}$ for $45 \mathrm{sec}, 57^{\circ} \mathrm{C}$ for $45 \mathrm{sec}$, and $72^{\circ} \mathrm{C}$ for $45 \mathrm{sec}$; for c-Mpl, $5^{\prime}$-ACCTTTGGAACCC GGTATGTG-3' and 5'-CTGTGGAGAGCAGCTGAATG-3', with 35 cycles at $95^{\circ} \mathrm{C}$ for $30 \mathrm{sec}, 55^{\circ} \mathrm{C}$ for $30 \mathrm{sec}$, and $72^{\circ} \mathrm{C}$ for $30 \mathrm{sec}$; for MOZ, 5' -TGTATCTGCTGCCTGTGGAG-3' and 5'CCCGGTTCTGCTCTTTTGTA-3', with 35 cycles at $95^{\circ} \mathrm{C}$ for $1 \mathrm{~min}, 60^{\circ} \mathrm{C}$ for $1 \mathrm{~min}, 72^{\circ} \mathrm{C}$ for $1 \mathrm{~min}$; for c-Kit, $5^{\prime}$-ACAGGAG CAGAGCAAAGGTG-3' and 5'-CGACCACAAAGCCAATGA GC- $3^{\prime}$, with 35 cycles at $95^{\circ} \mathrm{C}$ for $1 \mathrm{~min}, 60^{\circ} \mathrm{C}$ for $1 \mathrm{~min}$, and $72^{\circ} \mathrm{C}$ for $1 \mathrm{~min}$; and for $\beta$-actin, $5^{\prime}$-GAGAGGGAAATCGTGC GTGA-3' and $5^{\prime}$-ACATCTGCTGGAAGGTGGAC-3', with 25 cycles at $95^{\circ} \mathrm{C}$ for $30 \mathrm{sec}, 57^{\circ} \mathrm{C}$ for $30 \mathrm{sec}$, and $72^{\circ} \mathrm{C}$ for $1 \mathrm{~min}$.

\section{Immunoprecipitation, immunoblotting, and antibodies}

For immunoprecipitation, cell lysates were prepared in lysis buffer ( $250 \mathrm{mM} \mathrm{NaCl}, 20 \mathrm{mM}$ sodium phosphate at $\mathrm{pH} 7.0,30$ $\mathrm{mM}$ sodium pyrophosphate, $10 \mathrm{mM} \mathrm{NaF}, 0.1 \% \mathrm{NP}-40,5 \mathrm{mM}$ DTT, $1 \mathrm{mM}$ phenylmethyl sulfonyl fluoride [PMSF]) supplemented with complete protease inhibitor (Roche). After removal of cell debris by ultracentrifugation at $4^{\circ} \mathrm{C}$ and 40,000 rpm for $30 \mathrm{~min}$, the supernatant was incubated with anti-Flag antibody-conjugated agarose beads (Sigma) and slowly rotated at $4^{\circ} \mathrm{C}$ for $8-10 \mathrm{~h}$. Beads were then extensively washed with lysis buffer. Precipitated proteins were eluted from the beads with $200 \mu \mathrm{L}$ of lysis buffer containing Flag peptide at a final concentration of $2 \mathrm{mg} / \mathrm{mL}$. The eluate was concentrated using filtration devices (Vivaspin 10K-PES, Sartorius) and dissolved with the same volume of $2 \times$ SDS-PAGE sample buffer $(125 \mathrm{mM}$ Tris$\mathrm{HCl}, 4 \%$ SDS, 10\% $\beta$-mercaptoethanol), followed by SDSPAGE. When immunoprecipitation was not performed, total protein lysates were prepared in $2 \times$ SDS-PAGE sample buffer. Antibodies were detected by chemiluminescence using ECL plus Detection Reagents (Amersham Pharmacia Biotech). AntiFlag (M2) (Sigma), anti-HA (3F10) (Roche), anti-human AML rabbit polyclonal, anti-MOZ rabbit polyclonal (N) and (C) (Kitabayashi et al. 2001a), anti-PU.1 rabbit polyclonal, and antip300 rabbit polyclonal (N15) (Santa Cruz) antibodies were used as primary antibodies in this study.

\section{Luciferase assay}

SaOS2 cells or $293 \mathrm{~T}$ cells were transfected using the calcium phosphate precipitation method in 24-well plates, and luciferase activity was assayed after $24 \mathrm{~h}$ with a luminometer, Lumat LB9507 (Berthold), according to the manufacturer's protocol (Promega). Results of reporter assays represent the mean values for relative luciferase activity generated from three independent experiments normalized against the activity of the enzyme from phRL-CMV as an internal control.

\section{Acknowledgments}

We thank Dr. T. Okuda (Kyoto Prefectural University), Dr. H. Yoshida, and Dr. M Ohki (National Cancer Center Research
Institute) for discussion, and Ms. Kazumi Kimura, Ms. Noriko Aikawa, and Ms. Sachiyo Mitani for technical assistance. This work was supported in part by Grants-in-Aid for Scientific Research from the Ministry of Health, Labour, and Welfare and from the Ministry of Education, Culture, Sports, Science, and Technology, and by the Program for Promotion of Fundamental Studies from the National Institute of Biomedical Innovation of Japan.

\section{References}

Antonchuk, J., Hyland, C.D., Hilton, D.J., and Alexander, W.S 2004. Synergistic effects on erythropoiesis, thrombopoiesis, and stem cell competitiveness in mice deficient in thrombopoietin and steel factor receptors. Blood 104: 1306-1313.

Borrow, J., Stanton Jr., V.P., Andresen, J.M., Becher, R., Behm, F.G., Chaganti, R.S., Civin, C.I., Disteche, C., Dube, I., Frischauf, A.M., et al. 1996. The translocation $\mathrm{t}(8 ; 16)(\mathrm{p} 11 ; \mathrm{p} 13)$ of acute myeloid leukaemia fuses a putative acetyltransferase to the CREB-binding protein. Nat. Genet. 14: 33-41.

Bristow, C.A. and Shore, P. 2003. Transcriptional regulation of the human MIP-1 $\alpha$ promoter by RUNX1 and MOZ. Nucleic Acids Res. 31: 2735-2744.

Calvo, K.R., Sykes, D.B., Pasillas, M., and Kamps, M.P. 2000. Hoxa9 immortalizes a granulocyte-macrophage colonystimulating factor-dependent promyelocyte capable of biphenotypic differentiation to neutrophils or macrophages, independent of enforced meis expression. Mol. Cell. Biol. 20: 3274-3285.

Carapeti, M., Aguiar, R.C., Goldman, J.M., and Cross, N.C. 1998. A novel fusion between $\mathrm{MOZ}$ and the nuclear receptor coactivator TIF2 in acute myeloid leukemia. Blood 91: 3127-3133.

Carver-Moore, K., Broxmeyer, H.E., Luoh, S.M., Cooper, S., Peng, J., Burstein, S.A., Moore, M.W., and de Sauvage, F.J. 1996. Low levels of erythroid and myeloid progenitors in thrombopoietin- and c-mpl-deficient mice. Blood 88: 803808.

Chaffanet, M., Gressin, L., Preudhomme, C., Soenen-Cornu, V., Birnbaum, D., and Pebusque, M.J. 2000. MOZ is fused to p300 in an acute monocytic leukemia with $\mathrm{t}(8 ; 22)$. Genes Chromosomes Cancer 28: 138-144.

Champagne, N., Pelletier, N., and Yang, X.J. 2001. The monocytic leukemia zinc finger protein MOZ is a histone acetyltransferase. Oncogene 20: 404-409.

Debernardi, S., Lillington, D.M., Chaplin, T., Tomlinson, S., Amess, J., Rohatiner, A., Lister, T.A., and Young, B.D. 2003. Genome-wide analysis of acute myeloid leukemia with normal karyotype reveals a unique pattern of homeobox gene expression distinct from those with translocation-mediated fusion events. Genes Chromosomes Cancer 37: 149-158.

Deguchi, K., Ayton, P.M., Carapeti, M., Kutok, J.L., Snyder, C.S., Williams, I.R., Cross, N.C., Glass, C.K., Cleary, M.L., and Gilliland, D.G. 2003. MOZ-TIF2-induced acute myeloid leukemia requires the $\mathrm{MOZ}$ nucleosome binding motif and TIF2-mediated recruitment of CBP. Cancer Cell 3: 259-271.

Growney, J.D., Shigematsu, H., Li, Z., Lee, B.H., Adelsperger, J., Rowan, R., Curley, D.P., Kutok, J.L., Akashi, K., Williams, I.R., et al. 2005. Loss of Runx1 perturbs adult hematopoiesis and is associated with a myeloproliferative phenotype. Blood 106: 494-504.

Heller, P.G., Glembotsky, A.C., Gandhi, M.J., Cummings, C.L., Pirola, C.J., Marta, R.F., Kornblihtt, L.I., Drachman, J.G., and Molinas, F.C. 2005. Low Mpl receptor expression in a pedigree with familial platelet disorder with predisposition to acute myelogenous leukemia and a novel AML1 mutation. 
Blood 105: 4664-4670.

Huntly, B.J., Shigematsu, H., Deguchi, K., Lee, B.H., Mizuno, S., Duclos, N., Rowan, R., Amaral, S., Curley, D., Williams, I.R., et al. 2004. MOZ-TIF2, but not BCR-ABL, confers properties of leukemic stem cells to committed murine hematopoietic progenitors. Cancer Cell 6: 587-596.

Ichikawa, M., Asai, T., Saito, T., Seo, S., Yamazaki, I., Yamagata, T., Mitani, K., Chiba, S., Ogawa, S., Kurokawa, M., et al. 2004. AML-1 is required for megakaryocytic maturation and lymphocytic differentiation, but not for maintenance of hematopoietic stem cells in adult hematopoiesis. Nat. Med. 10: 299-304.

Imamura, T., Kakazu, N., Hibi, S., Morimoto, A., Fukushima, Y., Ijuin, I., Hada, S., Kitabayashi, I., Abe, T., and Imashuku, S. 2003. Rearrangement of the MOZ gene in pediatric therapy-related myelodysplastic syndrome with a novel chromosomal translocation $\mathrm{t}(2 ; 8)(\mathrm{p} 23 ; \mathrm{p} 11)$. Genes Chromosomes Cancer 36: 413-419.

Iwasaki, H., Somoza, C., Shigematsu, H., Duprez, E.A., IwasakiArai, J., Mizuno, S., Arinobu, Y., Geary, K., Zhang, P., Dayaram, T., et al. 2005. Distinctive and indispensable roles of PU.1 in maintenance of hematopoietic stem cells and their differentiation. Blood 106: 1590-1600.

Kim, H.G., de Guzman, C.G., Swindle, C.S., Cotta, C.V., Gartland, L., Scott, E.W., and Klug, C.A. 2004. The ETS family transcription factor PU.1 is necessary for the maintenance of fetal liver hematopoietic stem cells. Blood 104: 3894-3900.

Kimura, S., Roberts, A.W., Metcalf, D., and Alexander, W.S. 1998. Hematopoietic stem cell deficiencies in mice lacking c-Mpl, the receptor for thrombopoietin. Proc. Natl. Acad. Sci. 95: 1195-1200.

Kimura, M., Koseki, Y., Yamashita, M., Watanabe, N., Shimizu, C., Katsumoto, T., Kitamura, T., Taniguchi, M., Koseki, H., and Nakayama, T. 2001. Regulation of Th2 cell differentiation by mel-18, a mammalian polycomb group gene. Immunity 15: 275-287.

Kirito, K., Fox, N., and Kaushansky, K. 2004. Thrombopoietin induces HOXA9 nuclear transport in immature hematopoietic cells: Potential mechanism by which the hormone favorably affects hematopoietic stem cells. Mol. Cell. Biol. 24: 6751-6762.

Kitabayashi, I., Yokoyama, A., Shimizu, K., and Ohki, M. 1998. Interaction and functional cooperation of the leukemia-associated factors AML1 and p300 in myeloid cell differentiation. EMBO J. 17: 2994-3004.

Kitabayashi, I., Aikawa, Y., Nguyen, L.A., Yokoyama, A., and Ohki, M. 2001a. Activation of AML1-mediated transcription by MOZ and inhibition by the MOZ-CBP fusion protein. EMBO J. 20: 7184-7196.

Kitabayashi, I., Aikawa, Y., Yokoyama, A., Hosoda, F., Nagai, M., Kakazu, N., Abe, T., and Ohki, M. 2001b. Fusion of MOZ and p300 histone acetyltransferases in acute monocytic leukemia with a $\mathrm{t}(8 ; 22)(\mathrm{p} 11 ; \mathrm{q} 13)$ chromosome translocation. Leukemia 15: 89-94.

Kroon, E., Krosl, J., Thorsteinsdottir, U., Baban, S., Buchberg, A.M., and Sauvageau, G. 1998. Hoxa9 transforms primary bone marrow cells through specific collaboration with Meisla but not Pbx1b. EMBO J. 17: 3714-3725.

Lawrence, H.J., Helgason, C.D., Sauvageau, G., Fong, S., Izon, D.J., Humphries, R.K., and Largman, C. 1997. Mice bearing a targeted interruption of the homeobox gene HOXA9 have defects in myeloid, erythroid, and lymphoid hematopoiesis. Blood 89: 1922-1930.

Lawrence, H.J., Christensen, J., Fong, S., Hu, Y.L., Weissman, I., Sauvageau, G., Humphries, R.K., and Largman, C. 2005. Loss of expression of the HOXA-9 homeobox gene impairs the proliferation and repopulating ability of hematopoietic stem cells. Blood 106: 3989-3994.

Liang, J., Prouty, L., Williams, B.J., Dayton, M.A., and Blanchard, K.L. 1998. Acute mixed lineage leukemia with an inv(8)(p11q13) resulting in fusion of the genes for MOZ and TIF2. Blood 92: 2118-2122.

McKercher, S.R., Torbett, B.E., Anderson, K.L., Henkel, G.W., Vestal, D.J., Baribault, H., Klemsz, M., Feeney, A.J., Wu, G.E., Paige, C.J., et al. 1996. Targeted disruption of the PU.1 gene results in multiple hematopoietic abnormalities. EMBO J. 15: 5647-5658.

Miller, C.T., Maves, L., and Kimmel, C.B. 2004. moz regulates Hox expression and pharyngeal segmental identity in zebrafish. Development 131: 2443-2461.

Nakayama, T., June, C.H., Munitz, T.I., Sheard, M., McCarthy, S.A., Sharrow, S.O., Samelson, L.E., and Singer, A. 1990. Inhibition of $\mathrm{T}$ cell receptor expression and function in immature CD4+CD8+ cells by CD4. Science 249: 1558-1561.

Niki, M., Okada, H., Takano, H., Kuno, J., Tani, K., Hibino, H., Asano, S., Ito, Y., Satake, M., and Noda, T. 1997. Hematopoiesis in the fetal liver is impaired by targeted mutagenesis of a gene encoding a non-DNA binding subunit of the transcription factor, polyomavirus enhancer binding protein 2/core binding factor. Proc. Nat1. Acad. Sci. 94: 5697-5702.

Okuda, T., van Deursen, J., Hiebert, S.W., Grosveld, G., and Downing, J.R. 1996. AML1, the target of multiple chromosomal translocations in human leukemia, is essential for normal fetal liver hematopoiesis. Cell 84: 321-330.

Rosenbauer, F., Wagner, K., Kutok, J.L., Iwasaki, H., Le Beau, M.M., Okuno, Y., Akashi, K., Fiering, S., and Tenen, D.G. 2004. Acute myeloid leukemia induced by graded reduction of a lineage-specific transcription factor, PU.1. Nat. Genet. 36: 624-630.

Sasaki, K., Yagi, H., Bronson, R.T., Tominaga, K., Matsunashi, T., Deguchi, K., Tani, Y., Kishimoto, T., and Komori, T. 1996. Absence of fetal liver hematopoiesis in mice deficient in transcriptional coactivator core binding factor $\beta$. Proc. Natl. Acad. Sci. 93: 12359-12363.

Scott, E.W., Simon, M.C., Anastasi, J., and Singh, H. 1994. Requirement of transcription factor PU.1 in the development of multiple hematopoietic lineages. Science 265: 1573-1577.

So, C.W., Karsunky, H., Wong, P., Weissman, I.L., and Cleary, M.L. 2004. Leukemic transformation of hematopoietic progenitors by MLL-GAS7 in the absence of Hoxa7 or Hoxa9. Blood 103: 3192-3199.

Socolovsky, M., Nam, H., Fleming, M.D., Haase, V.H., Brugnara, C., and Lodish, H.F. 2001. Ineffective erythropoiesis in Stat5a-/-5b-/- mice due to decreased survival of early erythroblasts. Blood 98: 3261-3273.

Thomas, T., Voss, A.K., Chowdhury, K., and Gruss, P. 2000. Querkopf, a MYST family histone acetyltransferase, is required for normal cerebral cortex development. Development 127: 2537-2548.

Wang, Q., Stacy, T., Binder, M., Marin-Padilla, M., Sharpe, A.H., and Speck, N.A. 1996a. Disruption of the Cbfa2 gene causes necrosis and hemorrhaging in the central nervous system and blocks definitive hematopoiesis. Proc. Natl. Acad. Sci. 93: 3444-3449.

Wang, Q., Stacy, T., Miller, J.D., Lewis, A.F., Gu, T.L., Huang, X., Bushweller, J.H., Bories, J.C., Alt, F.W., Ryan, G., et al. 1996b. The CBF $\beta$ subunit is essential for CBF 2 (AML1) function in vivo. Cell 87: 697-708.

Waskow, C., Paul, S., Haller, C., Gassmann, M., and Rodewald, H.R. 2002. Viable c-Kit(W/W) mutants reveal pivotal role for c-kit in the maintenance of lymphopoiesis. Immunity 17: 277-288. 


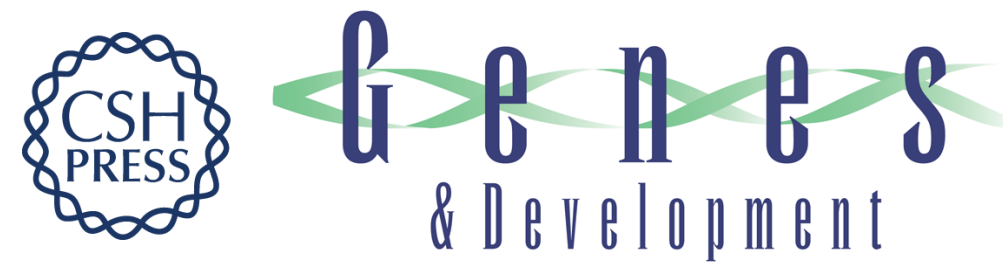

\section{MOZ is essential for maintenance of hematopoietic stem cells}

Takuo Katsumoto, Yukiko Aikawa, Atsushi Iwama, et al.

Genes Dev. 2006, 20:

Access the most recent version at doi:10.1101/gad.1393106

Supplemental Material

References License

Email Alerting Service
http://genesdev.cshlp.org/content/suppl/2006/04/27/20.10.1321.DC1

This article cites 41 articles, 24 of which can be accessed free at: http://genesdev.cshlp.org/content/20/10/1321.full.html\#ref-list-1

Receive free email alerts when new articles cite this article - sign up in the box at the top right corner of the article or click here.

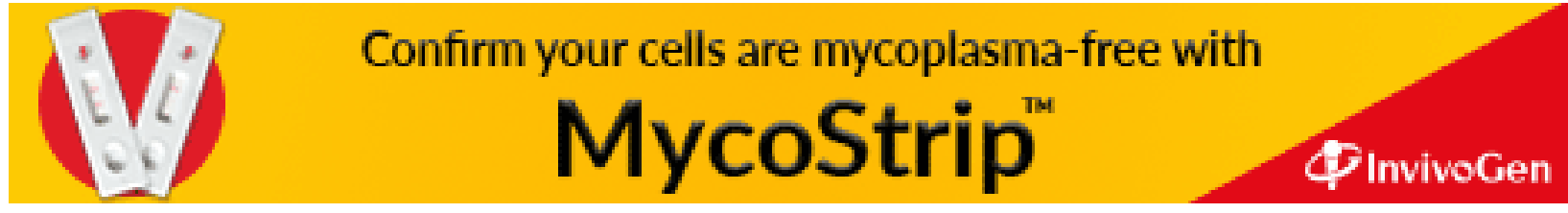

